\title{
The Choice of Schooling for the Next Moroccan Generation
}

\author{
I. Kissani, A. Boudihaj, and B. Boussouab
}

\begin{abstract}
The present study focuses on the impact of the current Moroccan educational system on Moroccan university students' choice of their graduate studies' country and their kids schooling. The targeted population consists of students who attended public and private Moroccan schools, and international schools (i.e. French, Spanish, and the American schools). The findings show that the majority have not chosen Morocco as a location for their graduate education or work and that none of the respondents has chosen the public Moroccan school for their kids schooling. This is mainly due to the unfortunate conditions faced by Moroccan children in schools that lack the basic infrastructure and technology resources conducive to learning.
\end{abstract}

Index Terms-Moroccan education for next generation, choice of graduate studies location, choice of kids schooling.

\section{INTRODUCTION}

Although Morocco has been working on reducing the rate of illiteracy since independence in 1956, which was at that time around $87 \%$, adults' illiteracy still remains very high, at around $20 \%$ in 2016. In rural areas, illiteracy is still wide spread especially among women. Morocco went through 10 different governments alternating between conservatives, liberals, socialists and others. The political diversity of the different governments that have succeeded power and the different political agendas that have been brought forward by the different educational reforms and their inefficient implementation process have tremendously impacted the level of education in Morocco. There is a lack of a clear and a holistic vision for the educational system in Morocco. The educational reforms led by the Moroccan Ministry of education with Canadian collaboration in 2004 have not addressed all the stakeholders and remains thereof partial and not practical. The reforms lacked synchrony between the need of the Moroccan citizen in 21st century and the national curriculum. The reforms lack Moroccan ownership; the program revision was mainly inspired from the Canadian system and implemented without being properly tailored to the Moroccan educational system, which makes the latter still lagging behind and missing sustainability.

The Moroccan Educational reforms have neither been efficient nor effective for both teaching and learning, as they have been driven by political agendas and missing out on the major concerns of both teachers and learners. The classroom remains teacher-centered where the teacher is an authority figure and the only source of knowledge; the learning mainly focuses on the end product and not the learning process. In addition, the curriculum focuses on knowledge with no focus on life skills, communication skills, interpersonal skills, study skills, or critical thinking skills [1], [2]. There is also absence of in-service training for teachers to prepare them to adopt new approaches and paradigms in teaching oriented towards ideas that can change the world [3], [4]. Burdened by a large class size, a heavy teaching schedule and rigid national curricula, schools teachers do not engage students in critical and creative thinking and in generating innovative ideas for the learners [5]-[8]. As a result, the learners are offered an education that does not mesh with a world of exponentially increasing information and changing technology [9].

The current educational system leaves us with learners who are frustrated, disengaged, underperforming, demotivated and with no faith in the Moroccan educational system. Unfortunately, this is not the only problem; education in Morocco is subject to other problems at the level of governance. There is poor ethical performance in all governmental units, absence of continuity among educational governmental units over time and lack of a collaborative spirit among different governmental units, which badly affects the quality of the Moroccan education. According to the Organization for Economic Cooperation and Development's (OECD) latest Program of International student Assessment ( PISA) survey in 2016, which evaluates the quality, equity and efficiency of school systems, Morocco is ranked 101 out of 134 countries and one of the lowest ranked Arab countries in the MENA region, preceding Egypt, Mauritania and Algeria as cited in a report prepared by the high council of education, training, and scientific research in Morocco in 2015 [9].

A number of studies discussing the reforms of the educational system acknowledges the efforts made to improve the level of education in Morocco. They all agree that many areas still need major improvements [10], [11]. The reforms have not really achieved the desired outcomes as the level of education remains very low, the number of school drop outs is still high, student achievement in science and reading is very low and the number of unemployed degree holders remains high. This has led many people to lose faith in the Moroccan schools and look for other existing and alternative educational systems for their kids.

\section{SURVEY DESCRIPTION}

\section{A. Survey Context}

Manuscript received December 15, 2017; revised May 15, 2018.

The authors are with Al Akhawayn University, Morocco (e-mail: I.Kissani@aui.ma). 
The study looks at how the current Moroccan educational system influences the future of the education of the Moroccan citizens. More specifically, the study attempts to find out whether the current Moroccan educational system influences the choice of university undergraduate students for their kids' schooling and their graduate education location. To answer this research question, the study looks at three main variables in the Moroccan educational system as good indicators of quality education, mainly the teaching methods, reading skills, and the diversity of the curriculum (including art, sport). To this end, a survey has been developed to study the impact of the three above variables on the respondents' choices of schooling and graduate education.

\section{B. Sample Representativeness}

The survey conducted targeted a large sample of students and employees (300) having attended both public and private schools (either Moroccan or international schools), and Moroccan public and private universities. The observations made on the studied samples are used to make inferences about the future of education of Moroccans in terms of the choice of their kids schooling. The sample studied is representative of the population of interest, which will help generalize the conclusions drawn from the survey results to the whole population. The results obtained from surveying a selected group of private university students and public university students, are an estimation of what could have been obtained if the survey was taken by every student studying in Morocco. The same remark holds true for those who have attended the private or the public schooling.

\section{RESULTS}

The answers collected show some strong correlations between some variables.

\section{A. Indicators of Quality Education}

Most of the respondents believe that the quality of teaching is bad and the content delivery is poor. The teacher is not perceived as a facilitator or a coach rather a disseminator of knowledge and an authority figure. With respect to reading skills, the survey's results show that students have only graded reading assignments. Most students who went to public and private Moroccan schools were encouraged to read for a grade, which makes us conclude that the Moroccan system does not really encourage reading for fun but it is rather imposed on students. The survey also demonstrated that less than $30 \%$ from both sectors read for assignment requirements as well as for fun.

The curriculum lacks diversity as it is overloaded with many content based subjects content, which makes students spend an average of a minimum 8 hours a day in the school to make sure that the syllabus is covered within the required time. This leaves students with a little exposure to art and sport. The students spend most of the day, moving from one lesson to another, with little or no time for physical education, artistic work or any other extracurricular activities. Only $23 \%$ of the respondents had exposure to art, namely theater and drawing in reduced forms at school. As per physical activities, the majority of the respondents admitted that sport was not part of the curriculum; any activities done by pupils were initiated by their families.

TABLE I: THE RESULTS OF T-TEST

\begin{tabular}{|c|c|c|}
\hline & Prv Univ & Pub Univ \\
\hline Mean & 0.265 & 0.209 \\
\hline Variance & 0.196 & 0.166 \\
\hline Observations & 147 & 110 \\
\hline Pooled Variance & 0.183 & \\
\hline Df & 255 & \\
\hline t Stat & 1.040 & \\
\hline $\mathrm{P}(\mathrm{T}<=\mathrm{t})$ one-tail & 0.149 & \\
\hline t Critical one-tail & 1.650 & \\
\hline $\mathrm{P}(\mathrm{T}<=\mathrm{t})$ two-tail & 0.299 & \\
\hline t Critical two-tail & 1.969 & \\
\hline
\end{tabular}

\section{B. Choice of Kids Schooling}

Relationships between variables pertaining to the objective of the study were found. Results from the survey show that all respondents $(15 \%)$ who studied in a Moroccan public school do not wish for their children to study in the same schooling system. The other $60 \%$ of the students who went to the Moroccan private school, $20 \%$ to French schools, $4 \%$ to an American school and $1 \%$ to a Spanish school wish to put their kids in the same educational system. $80 \%$ of the informants including those who went to the public and the private Moroccan schools prefer to put their children in a private Moroccan school. This means that $80 \%$ are satisfied with the quality of the Moroccan educational system but they are not satisfied with the teaching and learning conditions in the public Schools, which shows that they do not trust the Moroccan public educational system. They believe that the public sector has not achieved any goals, and it lacks the necessary infrastructure for a good education. The people who have gone to the public Moroccan school have regrets. Additionally, the remaining 20\% prefer an international school for their kids. The results also show that all those who studied in an international school, be it an American, a French or a Spanish School prefer to put their children in the same educational system where they studied. This leads us to conclude that they are almost $100 \%$ convinced that an international school offers the best education for their children.

From the inference statistics, using hypothesis testing analysis, it was derived that there is unanimity between those who attended public or non public schools in terms of the choice of a non public school for their kids. The findings of the statistical test of equality of means using T-distribution show that there is no difference between both groups in terms of the choice of non public schools for their kids. Even the dispersion among the two groups about the schooling choice for kids was not different to measure the spread of the data around the mean. Using Fisher, it is found that the 2 variances of the schooling choice for kids according to the above mentioned groups were quite similar, meaning that the dispersion is small for the two groups. 
In the upcoming tables the differences between the means and variances for the binary variable: schooling for kids (public vs non-public), of the two categories, people who attended public schools and those who attended private schools, were tested. The same is done for the other two categories, people who attended public universities and those who attended private universities.

TABLE II: THE RESULTS OF T-TEST AND FISHER TEST REGARDING THE CHOICE OF THE KIDS SCHOOLING FOR THOSE WHO ATTENDED PUBLIC UNIVERSITIES AND PRIVATE UNIVERSITIES

\begin{tabular}{|c|c|c|}
\hline \multicolumn{3}{|c|}{ F-Test Two-Sample for Variances } \\
\hline & Prv Univ & Pub Univ \\
\hline Mean & 0.818 & 0.920 \\
\hline Variance & 0.163 & 0.073 \\
\hline Observations & 11 & 139 \\
\hline Df & 10 & 138 \\
\hline $\mathrm{F}$ & 2.229 & \\
\hline$P(F<=f)$ one-tail & 0.019 & \\
\hline F Critical one-tail & 1.899 & \\
\hline \multicolumn{3}{|c|}{ t-Test: Two-Sample Assuming Unequal Variances } \\
\hline & Prv Univ & Pub Univ \\
\hline Mean & 0.818 & 0.909 \\
\hline Variance & 0.163 & 0.073 \\
\hline Observations & 11 & 139 \\
\hline Df & 11 & \\
\hline t Stat & -0.827 & \\
\hline $\mathrm{P}(\mathrm{T}<=\mathrm{t})$ one-tail & 0.212 & \\
\hline t Critical one-tail & 1.795 & \\
\hline $\mathrm{P}(\mathrm{T}<=\mathrm{t})$ two-tail & 0.425 & \\
\hline t Critical two-tail & 2.200 & \\
\hline
\end{tabular}

TABLE III: THE RESUlts OF T-TEST AND FISHER TEST REGARDING THE CHOICE OF THE Kids SCHOOLING For Those Who ATTENDEd Public SCHOOLS AND PRIVATE SCHOOLS

\begin{tabular}{lrr}
\hline \hline F-Test Two-Sample for Variances & & \\
& & \\
\hline Mean & Prv Schl & Pub Schl \\
Variance & 0.880 & 0.917 \\
Observations & 0.107 & 0.076 \\
Df & 42 & 193 \\
F & 41 & 192 \\
P(F<=f) one-tail & 1.405 & \\
F Critical one-tail & 0.066 & \\
\hline \hline
\end{tabular}

t-Test: Two-Sample Assuming Equal Variances

\begin{tabular}{lrr}
\hline & Prv Schl & Pub Schl \\
\hline Mean & 0.880 & 0.917 \\
Variance & 0.107 & 0.076 \\
Observations & 42 & 193 \\
Pooled Variance & 0.081 & \\
Df & 233 &
\end{tabular}

$$
\text { t Stat }
$$

$$
\mathrm{P}(\mathrm{T}<=\mathrm{t}) \text { one-tail }
$$

0.229

t Critical one-tail

$\mathrm{P}(\mathrm{T}<=\mathrm{t})$ two-tail

0.458

t Critical two-tail

1.970

\section{Choice of the Graduate Studies Country}

The survey also addressed the question with respect to the respondents' graduate studies. The findings show that the majority of the respondents from the public and the private school $\%$ and all those who went to an international school choose to continue their education abroad and even work overseas if they get a job. Here, we test for the difference between the means and variances for the binary variable: having or not overseas experience, of the two categories, people who attended public schools and those who attended private schools (i.e. Moroccan private and international schools). The same is done for other two categories, people who attended public universities and those who attended private universities.

- Fisher Tests and T-Tests (one model provided for sake of illustration)

The Fisher test is used to test the difference between the variances of the two categories (sub-samples):

$$
\begin{aligned}
& \mathrm{H}_{0}: \sigma_{2}=\sigma_{1} \\
& \mathrm{H}_{1}: \sigma_{2} \neq \sigma_{1}
\end{aligned}
$$

We have one tailed test so: $f$-stat $=1.06$ and f-critical $=$ 1.33 .

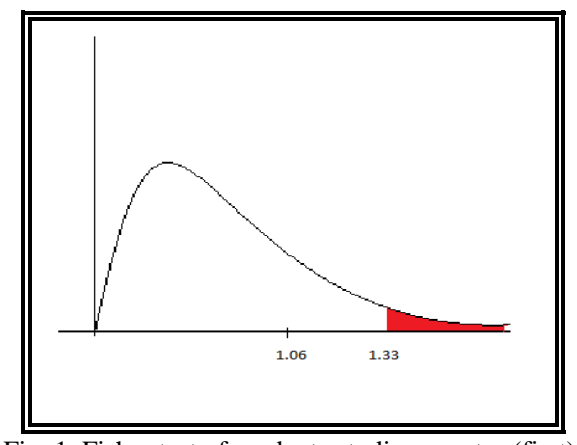

Fig. 1. Fisher test of graduate studies country (first).

$$
\begin{gathered}
\mathrm{H}_{0}: \mu_{1}-\mu_{2}=0 \\
\mathrm{H}_{1:} \mu_{1}-\mu_{2} \neq 0
\end{gathered}
$$

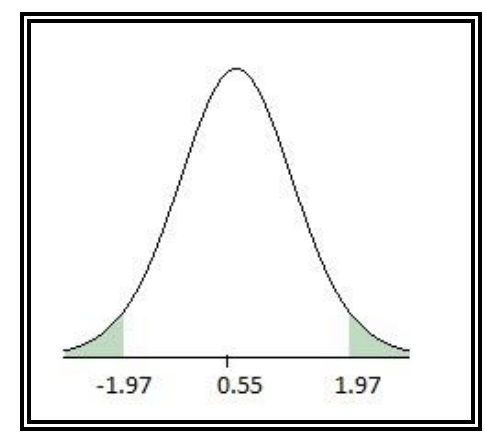

Fig. 2. T-test of graduate studies country (second).

Using the statistical tables of area under a normal curve with a $95 \%$ confidence interval, we have: 
Thus:

\section{$-1.96<$ Acceptance Region $<1.96$ with $\mathrm{t}-\mathrm{stat}=0.55$}

Since $\mathrm{t}$-stat $<$-t-critical and $\mathrm{f}$-stat<f-critical, we fail to reject Ho. So this allows us to come to the conclusion that the background of education doesn't have an impact on future generation schooling.

TABLE IV: THE RESULTS OF T-TEST AND FISHER TEST REGARDING THE CHOICE OF THE GRADUATE STUDIES COUNTRY FOR THOSE WHO ATTENDED PUBLIC UNIVERSITIES AND PRIVATE UNIVERSITIES

F-Test Two-Sample for Variances

\begin{tabular}{lrc}
\hline \hline & Prv Univ & Pub Univ \\
\hline Mean & 0.824 & 0.875 \\
Variance & 0.146 & 0.109 \\
Observations & 97 & 129 \\
Df & 96 & 128 \\
F & 1.333 & \\
P(F<=f) one-tail & 0.063 & \\
F Critical one-tail & 1.065 & \\
\hline \hline
\end{tabular}

t-Test: Two-Sample Assuming Equal Variances

\begin{tabular}{lrc}
\hline \hline & Prv Univ & Pub Univ \\
\hline \hline Mean & 0.824 & 0.87 \\
Variance & 0.146 & 0.11 \\
Observations & 97 & 129 \\
Pooled Variance & 0.125 & \\
Df & 224 & \\
t Stat & -1.077 & \\
P(T<=t) one-tail & 0.141 & \\
t Critical one-tail & 1.651 & \\
P(T<=t) two-tail & 0.282 & \\
t Critical two-tail & 1.970 & \\
\hline \hline
\end{tabular}

TABLE V: THE RESULTS OF T-TEST AND FISHER TEST REGARDING THE CHOICE OF THE GRAduATE STUdies COUNTRY FOR THOSE WHO ATTENDED PUBLIC SCHOOLS AND PRIVATE SCHOOLS

F-Test Two-Sample for Variances

\begin{tabular}{lcc}
\hline \hline & Prv Schl & Pub Schl \\
\hline Mean & 0.823 & 0.863 \\
Variance & 0.149 & 0.118 \\
Observations & 34 & 183 \\
Df & 33 & 182 \\
F & 1.263 & \\
P(F<=f) one-tail & 0.170 & \\
F Critical one-tail & 1.501 & \\
\hline \hline
\end{tabular}

t-Test: Two-Sample Assuming Equal Variances

\begin{tabular}{lrr}
\hline \hline & Prv Schl & Pub Schl \\
\hline Mean & 0.823 & 0.863 \\
Variance & 0.149 & 0.118 \\
Observations & 34 & 183 \\
Pooled Variance & 0.123 &
\end{tabular}

Df

215

t Stat

0.557

$\mathrm{P}(\mathrm{T}<=\mathrm{t})$ one-tail

0.272

t Critical one-tail

1.975

$\mathrm{P}(\mathrm{T}<=\mathrm{t})$ two-tail

0.544

t Critical two-tail

1.971

\section{DISCUSSION}

As expected, the majority of the respondents believe that a non-Moroccan educational system is an ideal choice for their graduate education studies. It seems that their lack of trust in the educational system in Morocco influence their choice for their future graduate education and professional experience. Most respondents prefer to look for jobs overseas and maybe settle there. This could also be a chance for their kids to have a better education. This dissatisfaction with the Moroccan education and desire to eventually migrate abroad is mainly driven by problems in the educational system, namely content delivery methods, teachers' poor pedagogical training, pupils poor reading skills. These problems are mainly due to poor administrative management, the insufficient budget allocated by the government to the educational sector and last but not least the limited access to a modernized education and the lack of advanced technologies in schools.

The quality of education, therefore, seems to influence students' choices of their future kids' education. Despite the fact that the Moroccan education went through major reforms in 2004 to improve the quality of education, these improvements have not transpired in the teaching pedagogies, learning methodologies or evaluation tools available to teachers. Most Moroccan children still have very poor reading skills or even severe reading difficulties. The educational reforms have not offered any evidence-based interventions to support their reading skills, especially in primary schools. The reading is mostly practiced during class time through reading aloud protocol, which is not very feasible in a large class size ( 30 to 40 students) and the reading assessment is mainly grade-oriented. Also, most schools have no libraries, access to child friendly literature or exposure to attractive and interactive activities.

In the absence of practical and interactive exercises and process-oriented methods related to teaching literacy in general, there is low confidence and motivation in reading among primary school pupils. When children are reading in response to an external factor, namely a grade, and not for enjoyment or a personal interest, they cannot be fully engaged or enthused when reading.

To address this problem, the Moroccan ministry of education should encourage reading for pleasure as it is essential in the development of literacy. Many studies have shown that the importance of reading for pleasure positively correlates with reading attainment and reading comprehension development [12]-[14]. Pupils should have access to libraries in schools and child friendly literature in classrooms as well as collaborative and interactive activities to help improve their reading skills and boost up their 
self-esteem. Reading skills are not only important to academic achievement but also to job acquisition and future success [15].

Another major problem that makes student lose trust in the Moroccan educational system is that it hardly focuses on artistic work or sports. The respondents mostly dislike the fact that schools do not bring focus on art or sport in their curriculum or extracurricular activities. The students have very limited exposure to a variety of artistic work or experience new forms of sport activities. Less than one hour is dedicated to artistic work and sport activities per week in the Moroccan curriculum for children at the primary level (informal discussion with school principals). The time for and range of sport and art activities in public schools fall well short of what might be found in a private school or what is found in an international school in Morocco. The Moroccan national curriculum has also no life skills. The traditional curriculum focuses mainly on overloading students with information and therefore gives them little room for personal development. There seems to be no activities that address the psychological development and emotional development of the student. These neglected aspects of development have a negative impact on the student growth.

Integrating art in the curriculum is central to development of educated people as the cultivation of their aesthetic sensibility gives them a sense of value, boosts their self-esteem and confidence, improves their interpersonal skills and develops their ethical behavior. "Too often our arts curriculums are inexistent or have gaps in effective exposure to and constructive experience with a varied selection of art forms," despite the fact that extensive research shows that integrating art in schools has an effect on the academic and social benefits in the long term kids, especially those who are economically disadvantaged [16]. A 2012 study by the United States' National Endowment for the Arts, for example, found that low-income eighth-graders who had lots of exposure to the arts were more likely than their peers with less exposure to earn higher grades and attend college [16].

The importance of continuous improvement is crucial for the educational development process. This means that reviewing and questioning the past practices and providing a follow-up for the recently implemented practices would help to maximize student learning and enhance the quality education, which remains the primary goal of all nations. The role of educational institutions is to provide the optimal favorable conditions to promote quality learning. Therefore, at the forefront in any considerations of quality in higher education should be the improvement of the student experience [17], [18].

\section{RECOMMENDATIONS AND CONCLUSION}

The majority of the respondents think that the educational system in Morocco needs a lot of improvement and development and that the Moroccan public schools are not the ideal place to choose if the parents are hoping for a bright future for their children. They, therefore, stress the importance to identify the flaws of the system so as to address them. When answering the open questions in the survey, the respondents suggest that, to improve the educational sector in Morocco, the government should increase the budget dedicated to education in order to provide well-maintained infrastructures, facilitate access to schooling, introduce new technologies to students and promote learning and personal development [19]. The ministry should also offer continuous trainings to professors and teachers to become facilitators, innovative and interactive teachers [3], [4] [18], and to substitute dated assessment with modern types of assessment [19]. Last but not least, they think that the Moroccan ministry of education should develop a customized educational system that suits the Moroccan ideology and culture instead of taking systems from other countries such as France or Canada that have proved inconvenient to the Moroccan society.

The respondents also suggested some immediate changes to embetter the level of education in Morocco. The national curriculum should integrate some real life problems in all science subjects (math, physics, and biology), implement some life skills classes (study skills, interpersonal good communication skills), and use technology in the classrooms (supplying schools with computers and smart screens). They further think that the Moroccan ministry of education should introduce a variety of art and sport activities (drama, theater, swimming), make reading as an interactive activity (paired reading, reading games) and focus on critical thinking skills problem solving and decision making).

This paper shows that the majority of Moroccan university students are disappointed with the Moroccan educational system. The current educational system has proved inconvenient to the Moroccan educated and informed citizens due to a dearth of evidence-based government interventions to address problems in the educational system in the primary and secondary school and high school.

This explains the choice of the respondents for their children's schooling. This choice has been relative to the parents' education; the overwhelming majority of the respondents who had Moroccan public and private schooling have chosen the private Moroccan schooling and partially international schooling while those who went to an international school have chosen the same education for their children. In other words, the aforementioned segment is also disappointed with the Moroccan educational system. This disappointment also influenced their choice of the country in which they want to pursue their graduate education and most probably settle if they find a job. Most Moroccan undergraduates' students think that an overseas experience for graduate studies and maybe work would be an opportunity to remediate gaps in their personal, emotional and critical thinking skills. Issues with the quality of education in Morocco may not be the only factor among others that influence peoples' choices for future education and eventually migration overseas. Future research should explore how other factors namely unethical practices and lack of institutionalized educational agendas impede efforts to improve education in Morocco.

\section{REFERENCES}

[1] H. H. Jacobs, "A new essential curriculum for a new time," Curriculum 21: Essential Education for a Changing World, 2010, ch. 1, pp. 7-17. 
[2] H. H. Jacobs, "Upgrading the curriculum: $21^{\text {st }}$ century assessment types and skills," Curriculum 21: Essential Education for a Changing World, ASCD, 2010, ch. 2, pp. 18-29.

[3] P. Sahlberg, Finnish Lessons: What Can the World Learn from Educational Change in Finland? Teachers College Press, 2015

[4] S. Wilmarth, "Five socio-technology trends that change. Everything in learning and teaching," Curriculum 21: Essential Education for a Changing World, ASCD, 2010, ch. 5, pp. 80-96.

[5] H. H. Jacobs, "New school versions: Reinventing and reuniting school program structures," Curriculum 21: Essential Education for a Changing World, ASCD, 2010, ch. 4, pp. 60-79.

[6] J. P. Cloud, "Educating for a sustainable future," Curriculum 21: Essential Education for a Changing World, ASCD, 2010, ch. 10, pp. 168-185.

[7] V. Stewart, "A classroom as wide as the world," Curriculum 21: Essential Education for a Changing World, ASCD, 2010, ch. 6, pp. 97-114.

[8] T. Tyson, "Making learning irresistible: Extending the journey of Mabry Middle School," Curriculum 21: Essential Education for a Changing World, ASCD, 2010, ch. 7, pp. 115-132.

[9] O. Azziman, "Strategic vision of the reform of the Moroccan School (2015-2030)," Higher Council for Education, Training and Scientific Research, Morocco, 2015.

[10] V. Llorent-Bedmar, "Educational reforms in Morocco: Evolution and current status," International Education Studies, vol. 7, no. 12, 2014.

[11] A. Ibourk and J. Amaghouss, "The performance of educational system in Morocco: A spatial analysis," Regional and Sectoral Economic Studies, vol. 14, issue 2, 2014.

[12] J. M. Warrington and G. Patricia, "Reading for pleasure in paradise: Paired reading in Antigua and Barbuda," Literacy, vol. 48, no. 2, pp. $66-71,2014$

[13] C. Clark and K. Rumbold, Reading for Pleasure: A Research Overview, London: National Literacy Trust, 2006.

[14] K. Cox and J. T Guthrie, "Motivational and cognitive contributions to students' amount of reading," Contemporary Educational Psychology, vol. 26, no. 1, pp. 116-131, 2001

[15] B. Jeffes, "Raising the reading skills of secondary-age students with severe and persistent reading difficulties: Evaluation of the efficacy and implementation of a phonics-based intervention programme," Educational Psychology in Practice, vol. 32, no. 1, pp. 73-84, 2016.
[16] J. S. Catterall, S. A. Dumais, and G. Hampden-Thompson, "The arts and achievement in at-risk youth," National Endowment for the Arts, 2012.

[17] M. Tam, Measuring Quality and Performance in Higher Education, Quality in Higher Education, vol. 7, no. 1, pp. 47-54, 2001.

[18] F. W. Baker, "Media literacy: $21^{\text {st }}$ century literacy skills," Curriculum 21: Essential Education for a Changing World, ASCD, 2010, ch. 8, pp. 133-152.

[19] H. H. Jacobs, "Upgrading content: Provocation, invigoration, and replacement," Curriculum 21: Essential Education for a Changing World, ASCD, 2010, ch. 3, pp. 30-59.

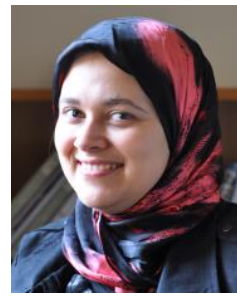

I. Kissani has a master and a Ph.D. from Laval University. She is a professor in the School of Science and Engineering at Al Akhawayn University. She works on the optimization models using various decision support systems. She has been the recipient of numerous Canadian awards and nominations (FORAC, NSERC). Her research interests include green and lean aspects in supply chain and logistics, and education.

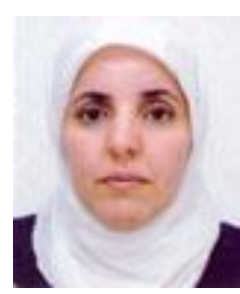

Awatif Boudihaj got her doctorate degree in education from Leeds University in UK. She joined Al Akhawayn University in August 2003. She has taught at the tertiary level both in Saudi Arabia and in the Sultanate of Oman. Her research interests involve writing, discourse analysis, needs analysis, computer assisted language learning (CALL) and developing students' research skills.

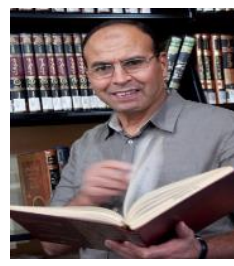

Brahim Boussouab has a doctorat d'Etat (2001) in arabic linguistics Universite Ibnou Zohr, Agadir, Morocco. He is a professor in School of Humanities and Social Sciences, Al Akhawayn University since 1995 . His research work is mainly on education. 